\title{
Ailelerin Erken Çocukluk Bakımı ve Eğitimi Dönemi Eğitim Harcamaları
}

DOI: 10.26466/opus.733398

\author{
$\underline{\text { Hüseyin Yolcu}}^{*}$ - Esra Yeşilyurt Yalçın ${ }^{* *}$ \\ * Prof. Dr., Kastamonu Ürrersitesi, Eğitim Fakültesi, Kastamonu/Türkiye \\ E-Posta: h.yolcu72@gmail.com \\ ORCID: 0000-0001-9974-8446 \\ ${ }^{*}$ Y. L. Öğrenci, Kastamonu Ümrersitesi, Sosyal Bilimler Enstitüsü, Kastamonu/Türkiye \\ E-Posta: yesilyurt10esraa@gmail.com \\ ORCID: 0000-0002-4283-4471
}

\begin{abstract}
Öz
Araştırmada, ailelerin erken çocukluk bakım ve eğitimi (EÇBE) döneminde yapmış oldukları eğitim harcamalarının ortaya konulması amaçlanmıştır. Araştırmanın çalışma grubunda Kastamonu il merkezinde 2017-2018 öğretim yılında çocukların kamu ve özel EÇBE okullarına gönderen 192 aile yer almaktadır. Araştırma tarama modelinde açıklayıcı bir araştırmadır. Araştırmanın verileri anket yolu ile toplanmıştır. Verilerin çözümlenmesinde betimsel istatistiklerin yanı sıra, nonparametrik testlerden Kruskal Wallis $H$ testine başvurulmuştur. Araştırmada, çocuklarını kamu EÇBE okullarına gönderen ailelerin ortalama 3.411,1 TL, çocukların özel EÇBE okullarına gönderen ailelerin de ortalama 6.222,4 $T L$ harcama yapmış olduğu belirlenmiştir. Ailelerin EÇBE eğitim harcamaları üzerinde çocuğun cinsiyeti, çocuğun devam ettiği okulun türü, çocuğun kiminle yaşadığı, baba eğitim, baba meslek, baba çalışma durumunun belirleyici olmadığı ancak, çocuğun devam ettiği okulun mülkiyeti, okula ulaşım türü, anne eğitim düzeyi, anne meslek, anne çalışma durumu, aile geliri ve hanedeki kişi sayısının belirleyici olduğu gözlenmiştir. Farklı aile yapılarında, EÇBE eğitim harcamaları üzerinde neden anne ile ilgili değişkenlerin daha belirleyici olduğu veya olmadı̆̆ının sosyal, ekonomik, kültürel boyutlarda sorgulayan bir araştırma yapılması önerilmektedir.
\end{abstract}

Anahtar Kelimeler: Erken çocukluk bakım ve eğitimi, Eğitim harcaması, Doğrudan eğitim harcaması, Dolaylı eğitim harcaması 


\title{
Families' Education Expenditures During Early Childhood Care and Education
}

\begin{abstract}
The study aims to reveal the educational expenditures of families during the early childhood care and education period (ECCE). 192 families whose children were enrolled in public or private ECCE schools in Kastamonu province center form the working group of the study. The study is a descriptive study done using the scanning method. The data for the study was collected through surveys. The analysis of the collected data was done via descriptive statistics and the nonparametric Kruksal Wallis $H$ test. The study reveals that the families whose children are enrolled in public ECCE schools, during the educational year, spent an average of 3.411,1 TL in total while families whose children are enrolled in private ECCE schools spent in average 6.222,4 TL. It was observed that the factors of the sex of the child, who the child lives with, the education level of the father, the employment status of the father, and the profession of the father were not decisive in the ECCE education expenditures the family makes but those of the transportation method to the school, the type of the school the child is enrolled, the education level of the mother, the employment status and profession of the mother, income of the family, and the population of the family were. It is hereby suggested that a study be done that questions from the social, economic, and cultural perspectives why the factors related with the mother are more (or less) decisive in ECCE education expenditures of different family types.
\end{abstract}

Keywords: Early childhood care and education period, education expenditure, direct educational expenditure, indirect educational expenditure 


\section{Giriş}

Erken çocukluk bakım ve eğitimi (EÇBE) çocuğun doğumundan zorunlu eğitim yaşına kadar olan yaşam dönemini kapsamaktadır. Ancak, bu konuda her ülkenin kendi yasal düzenlemeleri ve uygulamalarının farklı olduğu görülebilmektedir. Türkiye, Bangladeş, Brezilya, Mısır, Hindistan ve Meksika'da EÇBE dönemi için 0-6 yaş aralığı kabul görürken, Çin'de 0-7 yaş aralığ kabul görmektedir (Toran, 2011; The United Nations Educational, Scientific and Cultural Organization [UNESCO], 2004).

Yaşama, büyüme, gelişme ve bakımla ilgili süreçleri içeren EÇBE dönemi; fiziksel, bilişsel, dilsel ve sosyo-duygusal olmak üzere dört gelişim evresini içermektedir (Gordon ve Browne, 2011). Yüksek nitelikli EÇBE hizmetlerine katılım, bu hizmetlerden yararlanan bireylerin yanı sıra, toplumun geneline yönelik de kayda değer yarar sağlamaktadır. Örneğin, yapılan boylamsal araştırmalar; EÇBE'ye dahil olan çocukların dil ve okuryazarlık, yaratıcılık, müzik ve hareket, inisiyatif ve sosyal beceriler gibi gelişim alanlarına önemli ölçüde katkıda bulunduğunu ortaya koymaktadır (Bakken, Brown ve Downing, 2017; Barnett, 1995; Kağıtçıbaşı, Sunar, Bekman ve Cemalcılar, Mitchell, Wylie ve Carr, 2008).

Barnett (1995) EÇBE'nin yoksulluk, eşitsizlik, sosyal uyum ve kaynaştırma ile ilişkili yararları olduğunu belirtmektedir. Buna göre, EÇBE'nin göçmen ve düşük gelirli ailelerden gelen çocuklar üzerindeki yararları daha fazladır. Bu noktada, EÇBE belirtilen toplumsal kesimin çocukları için kayda değer bir biçimde eğitimde fursat eşitliği sağlamaktadır. Yüksek nitelikli EÇBE hizmetleri tüm çocukların potansiyellerini geliştirmelerine yardımcı olmanın ötesinde okul terki, yoksulluk riski ve sosyal dışlanmanın azaltılmasına da katkıda bulunmaktadır (Beşpınar ve Aybars, 2013).

Alanyazında yapılan çalışmalar, EÇBE hizmetlerinin ekonomi ve işgücü piyasasıyla olan yakın ilişkisini de ortaya koymaktadır. Buna göre, EÇBE'den yararlananların işgücü piyasasına dahil olma, kazanç, üretkenlik/verimlilik, istihdam edilebilirlik ve istihdam fırsatları diğerleriyle karşılaştırıldığında daha fazladır (Belle, 2016; Beşpınar ve Aybars, 2013; Kağıtçıbaşı ve diğerleri, 2005; Shomos, 2010). Örneğin, nitelikli EÇBE programlarına yapılan her 1 \$'lık yatırım ücret verimliliğinde 6-17 \$ arasında bir getiri sağlamaktadır (Save the Childeren, 2020). Bunun dişında, ailelerin yüksek nitelikli EÇBE 
hizmetlerine erişim olanağına sahip olması, öncelikle kadınların işgücü piyasasına aktif katılımını sağlamanın yanı sıra, iş yaşamına daha az süre ile ara vermeleri ya da yarı zamanlı bir işte çalışmalarının yerine tam zamanlı işte çalışmalarına olanak vermektedir (Yolcu, 2019).

Yukarıda belirtilenlerin dışında, EÇBE hizmetlerinin suç ve adaletle ilişkili yararları da bulunmaktadır. Örneğin, García ve Heckman ve Ziff'in (2019) yapmış oldukları araştırma bulgularına göre, yüksek nitelikli EÇBE hizmetlerinden yararlanma suç oranlarını düşürmede etkili olmaktadır. Yine bu araştırma bulguları, söz konusu durumun erkeklerden ziyade kadınlar üzerinde daha belirleyici olduğunu göstermektedir.

EÇBE'nin bireysel ve toplumsal yararlarına karşın finansmanının kim(ler) tarafından karşılanacağı bir tartışma konusudur. Genel olarak, EÇBE'nin biri kamu diğeri de özel kesim olmak üzere başlıca iki finansman kaynağı bulunmaktadır. Kamusal finansmanın kaynağı ya merkezi/ulusal hükümet ya da eyalet/yerel hükümet (yahut her ikisi de) olabilmektedir. Bu doğrultuda, gerek ulusal düzeyde gerekse yerel düzeyde EÇBE hizmetlerinin finansmanına eğitim, sağlık ve sosyal hizmetlerle ilgili kamu kurum ve kuruluşları da doğrudan veya dolaylı olarak destek vermektedir (Belfield, 2006). Endonezya'da 2014'te EÇBE'ye yönelik merkezi düzeyde 329,913,156 \$ harcama yapılırken, yerel düzeyde ise 183,631,666 \$ harcama yapılmıştır. Bu harcama miktarları Güney Kore'de sırasıyla; 8,867,000 \$ ve 927.000 \$ olarak gerçekleşmiştir (UNESCO, 2016). Türkiye' de 2018' de EÇBE hizmetlerine yönelik merkezi hükümet bütçesinden 9.735 milyon TL kaynak ayrılırken, yerel düzeyde ayrılan kaynak miktarı ise 146 milyon TL'dir (Türkiye İstatistik Kurumu [TÜIK], 2020).

EÇBE'nin diğer başlıca finansman kaynağı olan özel kesim ise aileler/hanehalkı ve özel tüzel kişilerin/özel sektörün yapmış olduğu eğitim harcamalarından oluşmaktadır (Belfield, 2006). Özel sektörün yapmış olduğu harcamalar dışarıda bırakıldığında, ailelerin EÇBE programlarına kayıt yaptırmaları tamamen ücretsiz olsa bile, ödeme güçlerine bağlı olarak bazı hizmetlerin finansmanına katkıda bulunmaları söz konusu olabilmektedir (Belfield, 2006; Ünal, 1996; Yolcu, 2011).

Ailelerin EÇBE hizmetlerinin finansmanına yönelik yapmış olduğu harcamalar; doğrudan ödemeler / harcamalar ve dolaylı ödemeler / harcamalar olmak üzere iki farklı biçiminde olmaktadır. Bunlardan ilki olan doğrudan 
harcamalar; okul giderleri (kayıt ücretleri, okul-aile birliği ücreti, sınav ücretleri, diploma, sertifika, öğrenci belgesi gibi ücretleri, fotokopi ücretleri ve kayıtla ilgili diğer ücretler); üniformalar, okul ekipmanları ve sarf malzemeleri (üniformalar ve zorunlu spor malzemeleri, zorunlı ders kitapları, alıştırma kitapları ile diğer okul malzemeleri) ile diğer ilişkili giderlerinden (otobüs, dolmuş biniş ücretleri, kantin ve kafeterya ücretleri, servis ücreti) oluşmaktadır. İkincisi olan dolaylı eğitim harcamaları ise zorunlu olmayan ders kitapları/yardımcı kaynaklar, okul dışı kitaplar, gazeteler, dergiler, bilgisayar donanımı, eğitici oyunlar, harçlık, boş zaman ve ders dışı faaliyetler, özel ders ve kurs vb. maliyetlerini içermektedir (Tiyab ve Ndabananiye, 2013). Örneğin, Türkiye'de ailelerin 2018' de yapmış oldukları EÇBE harcamalarının toplamı 2.146 milyon TL'dir (TÜIK, 2020).

Türkiye'de EÇBE ilköğretim okullarına bağlı resmi ana sınıfları, ilkokullara bağlı özel ana sınıfları, özel anaokulları, resmi anaokulları, 657 sayılı Kanun'un 191. maddesine göre açılan resmi kurumlar, Aile, Çalışma ve Sosyal Hizmetler Bakanlığına bağlı kurumlar, İş Kanunu'na göre işletmelerde açılan kreşler, yaz ve mobil anaokulları ve toplum temelli kurumlarında verilmektedir (Kaytaz ve Öztürk, 2019). Burada belirtilmesi gerekenlerden biri de Türkiye'de EÇBE'nin zorunlu eğitim kapsamında olmadığıdır. Söz konusu bu durum, ailelerin EÇBE hizmetlerinin finansmanındaki rolünü daha fazla ön plana çıkarmaktadır. Sarışık'ın (2019) ilgili araştırmasında, araştırmaya katılan her 10 aileden dokuzunun EÇBE'nin kamu tarafından finanse edilmesi gerektiğini belirtmesi de yukarıda belirtilenleri güçlenmektedir. Daha ötesi, EÇBE'nin ailelere olan finansman yükü 2018'de \%3,5 oranında bir artış göstermiştir (TÜİK, 2020).

Yukarıdaki açıklamalar dikkate alındığında, Türkiye'de ilgili alanyazında EÇBE finansmanını konu alan oldukça az sayıda araştırmaya ratlanılmaktadır (Bildirici, 2017; Saklan, 2011, Saklan ve Erginer, 2016; Sarışık, 2019). Bu araştırmalardan Bildirici'nin (2017) araştırması dışarda bırakıldığında, Saklan (2011), Saklan ve Erginer'in (2016) yanı sıra, Sarışık'ın (2019) araştırması ailelerin EÇBE eğitim harcamalarına ilişkin bulgular içermektedir. Dolayısıyla, belirtilen araştırmaların bu araştırma ile örtüşen yönleri söz konusudur. Ancak yapılan bu araştırma alanyazında yer alan diğer araştırmalardan birkaç yönden farklılaşmaktadır. Bunlardan ilki, bu araştırma çocuklarını kamu EÇBE okullarına gönderen ailelerin yanı sıra, özel EÇBE okullarına gönderen 
ailelerin eğitim harcamaların da içermektedir. İkincisi, ailelerin yapmış oldukları EÇBE harcamaları doğrudan ve dolaylı eğitim harcaması olarak iki alt harcama türüne göre sınıflandırılmıştır. Bir üçüncü farklılık ise ailelerin EÇBE eğitim harcamalarının farklı değişkenlere (çocukla ilgili, çocuğun devam ettiği okulla ilgili ve ailenin sosyo-ekonomik özellikleriyle ilgili) göre nasıl farklılık gösterdiğinin belirlenmeye çalışılmış olmasıdır.

Bu çalışmanın amacı, ailelerin EÇBE döneminde yapmış oldukları eğitim harcamalarının miktarı ve bu harcama miktarının farklı değişkenlere (çocuk, okul ve ailenin sosyo-demografik özellikleri) göre nasıl bir farklılaşma gösterdiğini ortaya koymaktır. Araştırma, 2017-2018 öğretim yılında ailelerin EÇBE okullarına (kamu ve özel) gönderdikleri bir çocuk için yapmış oldukları eğitim harcaması ile sınırlıdır. Elde edilen harcama miktarları yıllık ortalama değerleri yansıtmaktadır. Araştırmada aşağıdaki sorulara yanıt aranmiştır.

1. Ailelerin EÇBE döneminde yapmış olduğu toplam eğitim harcaması ne kadardır? Bu harcama miktarı çocuğun devam ettiği okulun kamu okulu ve özel okul olması bakımından değişkenlik göstermekte midir?

2. Ailelerin EÇBE döneminde yapmış oldukları doğrudan ve dolaylı eğitim harcaması ne kadardır? Bu harcama miktarları çocuğun devam ettiği okulun kamu okulu ve özel okul olması bakımından değişkenlik göstermekte midir?

3. Ailelerin EÇBE eğitim harcamaları; çocukla ilgili (cinsiyeti, çocuğun kiminle yaşadığı), okulla ile ilgili (mülkiyeti, ulaşım türü) ve sosyo-demografik (anne-babanın eğitim düzeyi, anne-babanın meslek durumu, annebabanın çalışma durumu, aile gelir düzeyi, hanede yaşayan kişi sayısı) değişkenlere göre anlamlı bir farklılık göstermekte midir?

\section{Yöntem}

Araştırma tarama modelinde betimsel bir araştırmadır. Tarama modeli araştırmalar, var olan bir durumu ve gerçekliği olduğu gibi ortaya koymayı hedeflemektedir. Buna göre, tarama modeli; araştırmanın odağında olan nesneye, olguya, olaya ve bireye vb. ilişkin şu andaki ya da geçmişteki verilerin tamamının sistematik bir biçimde gözden geçirilmesine dayanır (Şimşek, 2015). De Vaus (2002), tarama modeli araştırmalarının birkaç temel ayırt edici özelliğinin olduğunu belirtmektedir. Bunlardan ilki, araştırmada büyük bir 
topluluğun bir konuyla ilgili görüşlerinin betimlenmesi için uygun büyüklükte bir örneklem seçilmesidir. İkincisi, veri toplama yöntemleri ve teknikleri ile ilgilidir. $\mathrm{Bu}$ doğrultuda, tarama modeli araştırmalarda anketler d1şında, görüşme ve gözlem gibi diğer veri toplama yöntemleri de geniş bir biçimde kullanılır. Üçüncüsü ise araştırma verilerinin istatistiksel olarak çözümlenebilmesidir.Yapılan açklamalar doğrultusunda, araştırmanın belli bir büyüklükteki çalışma grubu üzerinden yürütülmesi, verilerin anket yolu ile elde edilmesi ve bu verilerin de istatistiksel olarak çözümlenmesi nedeniyle, tarama modelinde bir araştırma olduğu söylenebilir.

\section{Çalışma grubu}

Araştırmada, 2017-2018 öğretim yllında Kastamonu il merkezinde bulunan EÇBE döneminde eğitim hizmeti veren kamu okullarına ve özel okullara çocuklarını gönderen ailelerden gönüllü olanlar arasından bir çalışma grubu oluşturulmuştur. Araştırmanın çalışma grubuna dahil olacak ailelerin berlirlenmesinde, seçkisiz örnekleme türlerinden biri olan kolay/uygun örnekleme yöntemi kullanılmıştır. Uygun örnekleme yöntemi davranış bilimleri araştırmalarında en sık kullanılan örnekleme yöntemlerinden biri olarak bilinmektedir. Söz konusu bu yöntemde araştırmacılar kolayca ulaşılabildikleri bireyleri araştırmaya dahil edebilmektedir. Bu doğrultuda, katılımcilar araştırmaya uygunluklarının yanı sıra istek ve gönüllükleri doğrultusunda da araştırmaya katılmaktadır. (Gravetter ve Forzano, 2012, 2018).

Uygun örnekleme yöntemi, olasılık temelli örnekleme yöntemleriyle karşılaştırıldığında, araştırmacıya zaman, para ve işgücü kayıpları bakımından tasarruf sağlayan bir yöntemdir (Büyüköztürk, Çakmak, Aygün, Karadeniz ve Demirel, 2013; Gravetter ve Forzano, 2012, 2018). Bunula birlikte, bu yöntemle elde edilen sonuçların evrene genellenme-si söz konusu değildir (Creswell, 2012; Büyüköztürk ve diğerleri, 2013; Fraenkel ve Wallen, 2011; Gravetter ve Forzano, 2012, 2018).

Tablo 1'de araştırmaya dahil olan ailelerin EÇBE okullarına devam eden çocuklarının yan sıra, çocuğun gittiği okul ve bu ailelerin sosyo-ekonomik özelliklerine ilişkin bilgiler verilmiştir. 
Tablo 1. Çocuk, okul ve ailelerle ilgili bilgiler

\begin{tabular}{|c|c|c|c|}
\hline Değişken & & $\mathrm{n}$ & $\%$ \\
\hline \multirow{3}{*}{ Çocuğun cinsiyeti } & $\mathrm{K} 1 \mathrm{z}$ & 94 & 48,9 \\
\hline & Erkek & 98 & 51,1 \\
\hline & Toplam & 192 & 100,0 \\
\hline \multirow{5}{*}{ Çocuğun kiminle yaşadığı } & Anne-baba & 185 & 96,4 \\
\hline & Anne & 5 & 2,6 \\
\hline & Baba & 1 & 0,5 \\
\hline & Büyük ebeveyn(leri) & 1 & 0,5 \\
\hline & Toplam & 192 & 100,0 \\
\hline \multirow{2}{*}{ Okulun mülkiyeti } & Kamu & 27 & 14,1 \\
\hline & Özel & 165 & 85,9 \\
\hline \multirow{3}{*}{ Okulun türü } & Kreş & 37 & 19,3 \\
\hline & Anaokulu & 155 & 80,7 \\
\hline & Toplam & 192 & 100,0 \\
\hline \multirow{5}{*}{ Okula ulaşım } & Servis & 84 & 43,8 \\
\hline & Araba & 19 & 9,9 \\
\hline & Yaya & 87 & 45,3 \\
\hline & Toplu taşıma & 2 & 1,0 \\
\hline & Toplam & 192 & 100,0 \\
\hline \multirow{6}{*}{ Anne eğitim } & İkokul & 7 & 3,7 \\
\hline & Ortaokul & 6 & 3,1 \\
\hline & Lise & 35 & 18,3 \\
\hline & Üniversite & 116 & 60,7 \\
\hline & Lisansüstü & 26 & 13,6 \\
\hline & Toplam & 192 & 100,0 \\
\hline \multirow{6}{*}{ Baba eğitim } & İkokul & 5 & 2,7 \\
\hline & Ortaokul & 6 & 3,2 \\
\hline & Lise & 38 & 20,2 \\
\hline & Üniversite & 108 & 57,4 \\
\hline & Lisansüstü & 31 & 16,5 \\
\hline & Toplam & 192 & 100,0 \\
\hline \multirow{5}{*}{ Anne meslek } & İşçi & 6 & 3,1 \\
\hline & Memur & 95 & 49,5 \\
\hline & Serbest meslek & 34 & 17,7 \\
\hline & Çalışmıyor & 57 & 29,7 \\
\hline & Toplam & 192 & 100,0 \\
\hline \multirow{5}{*}{ Baba meslek } & İşçi & 23 & 12,0 \\
\hline & Memur & 99 & 51,6 \\
\hline & Esnaf & 16 & 8,3 \\
\hline & Serbest meslek & 54 & 28,1 \\
\hline & Toplam & 192 & 100,0 \\
\hline \multirow{3}{*}{ Anne çalışma durumu } & Özel Sektör & 23 & 12,0 \\
\hline & Kamu daimi kadrolu & 106 & 55,2 \\
\hline & Çalışmiyor & 57 & 29,7 \\
\hline
\end{tabular}




\begin{tabular}{|c|c|c|c|}
\hline & Kamu geçici işçi & 3 & 1,6 \\
\hline & Toplam & 192 & 100,0 \\
\hline \multirow{6}{*}{ Baba çalışma durumu } & Özel Sektör & 67 & 34,9 \\
\hline & Kamu daimi kadrolu & 113 & 58,9 \\
\hline & Kamu geçici işçi & 2 & 1,0 \\
\hline & Çalışmiyor & 4 & 2,1 \\
\hline & İşsiz & 6 & 3,1 \\
\hline & Toplam & 192 & 100,0 \\
\hline \multirow{5}{*}{ Aylık gelir/TL } & $1600-3000 \mathrm{TL}$ & 32 & 18,4 \\
\hline & $3001-5000 \mathrm{TL}$ & 49 & 28,2 \\
\hline & $50001-10000 \mathrm{TL}$ & 90 & 52,8 \\
\hline & $10001-18000 \mathrm{TL}$ & 3 & 1,7 \\
\hline & Toplam & 192 & 100,0 \\
\hline \multirow{8}{*}{ Hanedeki kişi sayısı } & 2 & 4 & 2,1 \\
\hline & 3 & 52 & 27,2 \\
\hline & 4 & 93 & 48,7 \\
\hline & 5 & 28 & 14,7 \\
\hline & 6 & 9 & 4,7 \\
\hline & 7 & 3 & 1,6 \\
\hline & 8 & 2 & 1,0 \\
\hline & Toplam & 192 & 100,00 \\
\hline
\end{tabular}

Tablo 1'deki bilgiler incelendiğinde, araştırma grubunda bulunan ailelerin çocuklarının 94'ü $(\% 48,9)$ kız, 98'i $(\% 51,1)$ ise erkektir. Bu çocukların 185'i $(\% 96,4)$ anne ve babasiyla, 5'i $(\% 2,6)$ annesi ile, 1'i $(\% 0,5)$ babası ile yine 1'i $(\% 0,5)$ de büyük eveveyn(ler)i ile yaşamaktadır. Ailelerin 27 'si $(\% 14,1)$ çocuklarını özel EÇBE okullarına, 165'i (\%85,9) ise kamu özel EÇBE okullarına göndermektedir. Çocukların 37' si (\%19,3) kreşe, 155'i i (\%80,7) anaokuluna devam etmekte olup bu çocukların $84^{\prime}$ ünün $(\% 43,8)$ okula ulaşımı servis aracryla sağlanırken, 19 'unun $(\% 9,9)$ aile bireyleri tarafından kendi arabalarıyla, 87 'sinin (\%45,3) okula ulaşımı ise yaya olarak ve 2 'sinin (\%1) de toplu taşıma araciyla olmaktadır.

Yine Tablo 1'e göre, annelerin 7'si (\%3,7) ilkokul, 6's1 (\%3,1) ortaokul, 35'i $(\% 18,3)$ lise, 116's1 (\%60,7) üniversite ve 26's1 (\%13,6) da lisansüstü eğitim mezunudur. Babaların 5'i (\%2,7) ilkokul, 6'sı (\%3,2) ortaokul, 38'i (\%20,2) lise, 108 'i $(\% 57,4)$ üniversite ve 31'i $(\% 16,5)$ lisansüstü mezunudur. Yine araştırmaya katılan ailelerde, annelerin 6'sının (\%3,1) mesleği işçi iken, 95'nin (\%49,5) memur, 34'ünün (\%17,7) serbest meslek, 57'sinin (\%29,7) de ev kadını olduğu veya evde çalıştığı görülmektedir. Babaların 23'ünün (\%12,0) mesleği işçi, 99'nun (\%51,6) memur, 16'sının (\%8,3) esnaf iken, 54'ünün $(\% 28,1)$ serbest meslek sahibi olduğu anlaşılmaktadır. 
Tablo 1'den görüleceği üzere, araştırmaya katılan ailelerde annelerin 23'ü (\%12) özel sektörde, 106'sı (\%55,2) kamuda daimi kadroda, 57'si $(\% 29,7)$ ev kadını/evde çalışmamakta, 3'ü $(\% 1,6)$ kamuda geçici işçi olarak çalışmaktadır. Babaların 113'ü $(\% 58,9)$ özel sektörde, 113'ü $(\% 58,9)$ kamuda daimi kadroda, 2'si (\%1) kamuda geçici işçi, 4'ü $(\% 2,1)$ herhangi bir işte çalışmamakta, 6's1 (\%3,1) da işsizdir. Ailelerin 32'si (\%18,4) 1600-3000 TL arasında, 49'u (\%28,2) 3001-5000 TL arasinda, 90'nı (\%52,8) 50001-10000 TL arasında ve 3'ü $(\% 1,7)$ ise 10000 TL ve üzeri aylık gelire sahiptir. Diğer yandan, ailelerin 4'ünde (\%2,1) handedeki kişi sayısı 2 kişi iken 52'sinde (\%27,2) 3 kişi, 93'ünde $(\% 48,7) 4$ kişi, 28 'inde $(\% 14,7) 5$ kişi, 9'unda $(\% 4,7) 6$ kişi, 3'ünde $(\% 1,6) 7$ kişi ve 8 'inde (\%1) ise 2 kişidir.

\section{Verilerin Çözümlenmesi}

Verilerin analizi yapılırken SPSS 22 paket programı kullanılmıştır. Araştırma verilerinin normal dağglım gösterip göstermediğini belirlemek için Kolmogorov Simirnov $Z$ testi uygulanmıştır. Ancak, yapılan bu test sonucunda verilerin normal dağılım göstermediği belirlenmiştir. Araştırmanın ilk iki alt amaçlarına ilişkin verilerin çözümlenmesinde betimsel istatistiklerden (aritmetik ortlama, yüzde ve frekans) yararlanılmıştır. Diğer yandan, araştırmanın üçüncü alt amacına ilişkin verilerin çözümlenmesine ise nonparametrik testlerden Kruskal Wallis U testine başvurulmuştur. Farklılaşmanın hangi gruplar arasında anlamlı olduğunu belirlemek için de Post Hoc testlerinden Tamhane testinden yararlanılmıştır.

\section{Bulgular}

Araştırmada elde edilen bulgular araştırmanın alt amaçlarına uygun olarak aşağıda verilmiştir.

Tablo 2'de ailelerin yapmış oldukları toplam EÇBE eğitim harcamalarına ilişkin bulgular bulunmaktadır. 
Tablo 2. Ailelerin toplam EÇBE eğitim harcamalarn (2018 yılı cari fiyatlarıyla/TL)

\begin{tabular}{|c|c|c|c|c|c|c|}
\hline \multirow[b]{2}{*}{$\begin{array}{l}\text { Okulun } \\
\text { Mülkiyeti }\end{array}$} & \multicolumn{6}{|c|}{ Harcama türü } \\
\hline & $\mathrm{n}$ & $\begin{array}{l}\text { Doğrudan } \\
\text { (1) }\end{array}$ & $(1) /(3) . \%$ & $\begin{array}{l}\text { Dolaylı } \\
\text { (2) }\end{array}$ & $(2) /(3) . \%$ & $\begin{array}{l}\text { Toplam } \\
\text { (3) }\end{array}$ \\
\hline Kamu & 165 & $2.561,1$ & 85,3 & 850 & 14,7 & $3.411,1$ \\
\hline Özel & 27 & $5.662,4$ & 91,3 & 560 & 8,7 & $6.222,4$ \\
\hline Toplam & 192 & $8.223,5$ & 90,2 & 1.410 & 9,8 & $9.633,5$ \\
\hline
\end{tabular}

Tablo 2'ye göre, çalışma grubundaki ailelerin EÇBE için yapmış oldukları toplam eğitim harcaması 9.633,5 TL'dir. Bu harcamanın 8.223,5 TL'si (\%90,2) doğrudan harcamalar; 1410 TL'si de $(\% 9,8)$ dolaylı harcamalar biçiminde gerçekleşmiştir. Konuya kamu ve özel EÇBE okulu ayrımı bakımından yaklaşılırsa; çocuklarını kamu EÇBE okullarına gönderen aileler 3.411,1 TL; özel EÇBE okullarına gönderen aileler de 6.222,4 TL eğitim harcaması yapmışlardır. Kamu EÇBE okullarına çocukların gönderen ailelerin yapmış oldukları harcamanın 2.561,1 TL'si (\% 85,3) doğrudan harcamalar, 850 TL' si (\% 14,7) de dolaylı harcamalar biçiminde gerçekleşmiştir. Çocuklarını özel EÇBE okullarına gönderen ailelerin yapmış oldukları harcamanin 5.662,4 TL'si (\% 91,3) doğrudan harcamalar, 560 TL'sinin (\% 8,7) de dolaylı harcamalar olduğu görülmektedir.

Ailelerin EÇBE'ye yönelik yapmış oldukları doğrudan eğitim harcamalarının, harcama kalemlerine göre dağglımına ilişkin bulgular Tablo 3'te verilmiştir.

Tablo 3'te görüldüğü üzere, ailelerin yapmış oldukları doğrudan eğitim harcaması 8.223,5 TL'dir. Bu harcamanın 2.561,1 TL'sini (\%31,1) çocuklarını kamu EÇBE okullarına gönderen aileler, 5.662,4 TL'sini de (\%68,9) çocuklarını özel EÇBE okullarına gönderen aileler yapmıştır. Ailelerin yapmış olduğu doğrudan eğitim harcamaları içinde en büyük harcama kaleminin okul aidatının/ücretinin olduğu anlaşılmaktadır. Buna göre, ailelerin okul aidatı için yaptıkları harcama miktarı 5.566,1 TL'dir. Yapılan harcamanın 1.356,8 TL'si $(\% 24,4)$ çocukların kamu EÇBE okullarına gönderen ailelerce yapılırken, 4.209,3 TL'si $(\% 75,6)$ de özel EÇBE okullarına gönderen ailelerce yapılmıştır. Diğer yandan, ailelerin bu harcama türü içinde oransal olarak en az miktarda yaptıkları harcama ise 48,9 TL $(\% 0,6)$ beslenme için yapılan harcamalardır. Bu harcama kalemine yönelik olarak çocuklarını kamu EÇBE okullarına gönderen aileler 11,8 TL $(\% 24,2)$ harcama yaparken, çocuklarını EÇBE özel okullarına gönderen aileler ise 37 TL $(\% 75,8)$ harcama yapmıştır. 
Tablo 3. Ailelerin EÇBE'ye yönelik doğrudan eğitim harcamalarnıın dağılımı (2018 yılı cari fiyatlaryla/TL)

\begin{tabular}{|c|c|c|c|c|c|c|}
\hline \multirow[b]{2}{*}{ Harcama Kalemi } & \multicolumn{6}{|c|}{ Doğrudan Harcama/TL } \\
\hline & $\begin{array}{l}\text { Kamu } \\
\text { (1) }\end{array}$ & $\begin{array}{l}(1) /(3) \\
\%\end{array}$ & $\begin{array}{l}\text { Özel } \\
\text { (2) }\end{array}$ & $\begin{array}{l}(2) /(3) . \\
\%\end{array}$ & $\begin{array}{l}\text { Toplam } \\
\text { (3) }\end{array}$ & $\%$ \\
\hline Okul-aile birliği ücreti & 72,7 & 81,3 & 16,7 & 18,7 & 89,3 & 1,1 \\
\hline Okul aidatı & 1356,8 & 24,4 & 4209,3 & 75,6 & $5.566,1$ & 67,7 \\
\hline Gönüllü yapılan bağışlar & 75,8 & 73,2 & 27,8 & 26,8 & 103,5 & 1,3 \\
\hline $\begin{array}{l}\text { Okul tarafından düzenlenen resmi tören, gösteriler, } \\
\text { belirli gün ve haftalar için yapılan harcamalar }\end{array}$ & 30,7 & 53,7 & 26,5 & 46,3 & 57,2 & 0,7 \\
\hline $\begin{array}{l}\text { Okulda ve evde kullanılacak boyama kitapları } \\
\text { için toplanan paralar }\end{array}$ & 49,3 & 36,8 & 84,4 & 63,2 & 133,7 & 1,6 \\
\hline $\begin{array}{l}\text { Okulda ve evde kullanılacak etkinlik kitapları } \\
\text { için toplanan paralar }\end{array}$ & 67,6 & 35,5 & 123,0 & 64,5 & 190,5 & 2,3 \\
\hline $\begin{array}{l}\text { Okulda ve evde kullanılacak diğer } \\
\text { kitaplar için toplanan paralar }\end{array}$ & 47,3 & 30,2 & 109,3 & 69,8 & 156,5 & 1,9 \\
\hline $\begin{array}{l}\text { Kırtasiye türü ders araç gereçleri için yapılan harca- } \\
\text { malar (beslenme çantası, boya kalemi, elişi kağıdı } \\
\text { vb.) }\end{array}$ & 237,3 & 40,6 & 346,7 & 59,4 & 584,0 & 7,1 \\
\hline $\begin{array}{l}\text { Okul forması uygulaması olan okullarda forma için } \\
\text { yapılan harcamalar }\end{array}$ & 5,8 & 5,6 & 98,5 & 94,5 & 104,3 & 1,3 \\
\hline Okul servisi için yapılan harcamalar & 443,4 & 45,0 & 542,6 & 55,0 & 986,0 & 12,0 \\
\hline Okula ulaşım için yapılan diğer harcamalar & 162,6 & 80,0 & 40,7 & 20,0 & 203,4 & 2,5 \\
\hline Okula götürülen beslenme için yapılan harcamalar & 11,8 & 24,2 & 37,0 & 75,8 & 48,9 & 0,6 \\
\hline Toplam & $2.561,1$ & 31,1 & $5.662,4$ & 68,9 & $8.223,5$ & $\begin{array}{l}100, \\
0\end{array}$ \\
\hline
\end{tabular}

Ailelerin EÇBE için yapmış oldukları dolaylı eğitim harcamalarının harcama kalemlerine göre dağılımına yönelik bulgular Tablo 4 'te verilmiştir.

Tablo $4^{\prime}$ te yer alan veriler incelendiğinde ailelerin EÇBE için yapmış oldukları dolaylı eğitim harcamalarınn $1.410 \mathrm{TL}$ olduğu görülmektedir. $\mathrm{Bu}$ harcamanın 850 TL'si $(\% 60,3)$ çocuklarını kamu EÇBE okullarına gönderen ailelerce yapılırken, 560 TL'si $(\% 39,7)$ de çocuklarını özel EÇBE okullarına gönderen ailelerce yapılmıştır. Ailelerine dolaylı eğitim harcamaları içinde en büyük harcama kalemini ise İngilizce, jimnastik, yüzme vb. branşlarda görev yapan öğretmen ücretleri için yapılan harcamalar oluşmaktadır. Bu harcama kalemine yönelik yapılan toplam harcama miktarının 471,2 TL (\%33,4) olduğu anlaşılmaktadır. Söz konusu bu harcama kalemine yönelik olarak çocuklarını kamu EÇBE okullarına gönderen aileler 424,7 TL (\%90,1), özel EÇBE okullarına gönderen aileler de 46,5 TL $(\% 9,9)$ harcamada bulunmuştur. Diğer yandan, ailelerin dolaylı eğitim harcamaları içinde en az yer tutan harcama 
kalemini ise teknolojik donanım $(\% 0,1)$ için yapılan harcamalar oluşturmaktadır. Buna göre, bu harcama kalemi için ailelerin yapmış olduğu harcama miktarı 1,82 TL'dir. Bu harcama kalemi için yapılan harcamaların tamamı çocuklarını kamu EÇBE okullarına gönderen ailelerce yapılmıştır.

Tablo 4. Ailelerin EÇBE'ye yönelik dolaylı eğitim harcamalan (2018 yılı cari fiyatlaryyla/TL)

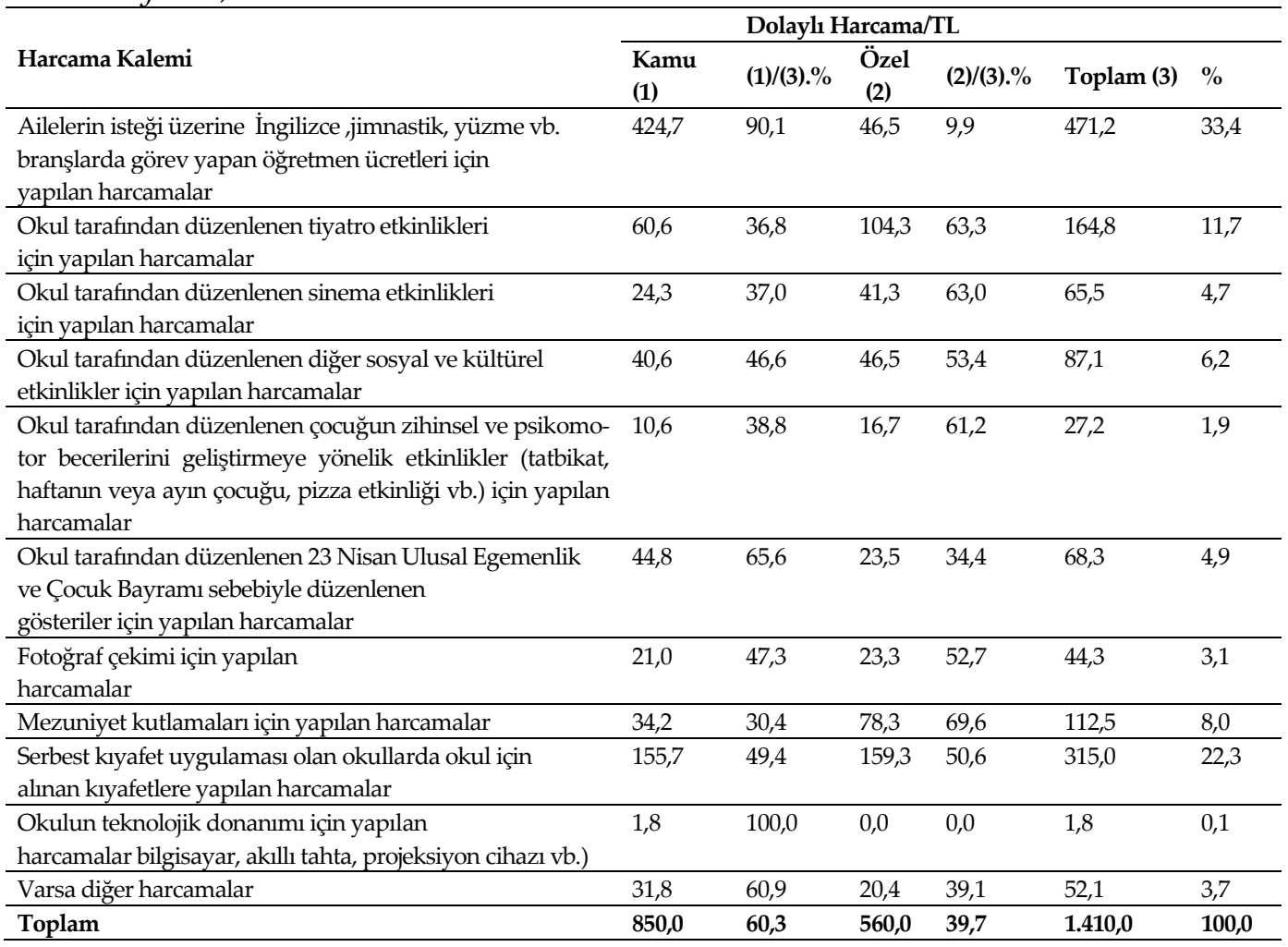

Çocuğun cinsiyetine göre ailelerin EÇBE eğitim harcamalarına yönelik Kruskal Wallis $\mathrm{H}$ testi sonuçları Tablo 5'te yer almaktadır.

Tablo 5. Çocuğun cinsiyetine göre, ailelerin EÇBE eğitim harcamalarna ilişkin kuruskal wallis $h$ testi sonuçlarn

\begin{tabular}{lllllll}
\hline Cinsiyet & $\mathrm{n}$ & $\mathrm{ST}$ & $\bar{X}$ & $\mathrm{U}$ & $\mathrm{z}$ & $\mathrm{p}^{*}$ \\
\hline Kız & 94 & 9051,50 & 96,29 & 4586,50 &,- 051 &, 960 \\
\hline Erkek & 98 & 9476,50 & 96,70 & & & \\
\hline
\end{tabular}

$\mathrm{P}>0.05$ 
Tablo 5'teki verilere bakıldığında, ailelerin EÇBE döneminde bulunan çocukları için yapmış oldukları eğitim harcaması, çocuğun cinsiyeti bakımından bir farklllık göstermemektedir.

Çocuğun ebeveynlerden hangisiyle yaşadığında göre, ailelerin yapmış olduğu EÇBE eğitim harcamalarına ilişkin Kruskal Wallis H Testi sonuçları Tablo 6'da yer almaktadır.

Tablo 6. Çocuğun kiminle yaşadığına göre, ailelerin EÇBE eğitim harcamalarna ilişkin kruskal wallis $h$ testi sonuçlarn

\begin{tabular}{lllllll}
\hline $\begin{array}{l}\text { Kiminle } \\
\text { Yaşadığı }\end{array}$ & $\mathbf{n}$ & $\bar{X}$ & Sd & $\mathbf{X}^{2}$ & $\mathbf{p}^{*}$ & Anlamlı fark \\
\hline $\begin{array}{l}\text { Anne-baba } \\
\text { Anne }\end{array}$ & 185 & 3766,42 & 3 &, 558 & 0,906 & - \\
\cline { 2 - 7 } & 5 & 5812,00 & & & & \\
Baba & 1 & 2040,00 & & & & \\
Diğer & 1 & 2940,00 & & & & \\
\hline
\end{tabular}

${ }^{*} \mathrm{p}>, 05$

Tablo 6'daki veriler incelendiğinde, ailelerin EÇBE eğitim harcamaları çocuğun kiminle yaşadığı bakımından bir farklılık göstermemektedir $\left(\mathrm{X}^{2}(3)=0,558, \mathrm{p}>0,05\right)$.

Ailelerin çocuklarını gönderdikleri okulun mülkiyetine göre yapmış oldukları EÇBE eğitim harcamalarını ortaya koymak için yapılan Kruskal Wallis $\mathrm{H}$ testi sonuçları Tablo 7'de verilmiştir.

Tablo 7. Okulun mülkiyetine göre, ailelerin EÇBE eğitim harcamalarna ilişkin kruskal wallis $h$ testi sonuçlar

\begin{tabular}{lllllll}
\hline $\begin{array}{l}\text { Okulun } \\
\text { Mülkiyeti }\end{array}$ & $\mathbf{n}$ & ST & SO & U & $\mathbf{z}$ & $\mathbf{p}^{*}$ \\
\hline $\begin{array}{l}\text { Kamu } \\
\text { Özel }\end{array}$ & 165 & 15230 & 92,3 & 1535 & $-2,587$ &, $01^{*}$ \\
\cline { 2 - 7 } & 27 & 3298 & 122,2 & & & \\
\hline${ }^{*} \mathrm{p}<, 05$ & & & & & &
\end{tabular}

Tablo 7'de yer alan veriler dikkate alındığında, ailelerin EÇBE eğitim harcamalarının çocuklarını gönderdikleri okulun kamu okulu ya da özel okul olması bakımından anlamlı bir şekilde farklılaştığı görülmektedir $(\mathrm{z}(192)=1535$; $\mathrm{p}<$,05). Buna göre, çocuklarını özel EÇBE okullarına gönderen ailelerin yapmış olduğu harcama çocuklarını kamu EÇBE okullarına gönderen ailelerin yaptığı harcamalardan fazladır. 
Okula ulaşım türüne göre, ailelerin EÇBE eğitim harcamalarına ilişkin Kruskal Wallis $\mathrm{H}$ testi verileri Tablo 8'de verilmiştir.

Tablo 8. Okula ulaşım türüne göre, ailelerin EÇBE eğitim harcamalarna ilişkin kruskal wallis $h$ testi sonuçlan

\begin{tabular}{|c|c|c|c|c|c|c|}
\hline Ulaşım Türü & $\mathbf{n}$ & $\bar{x}$ & Sd & $X^{2}$ & p & Anlamlı fark \\
\hline Servis aracı $(1)$ & 84 & 4305,9 & 3 & 16,029 & $0,001^{*}$ & $1-2$ \\
\hline Yaya (2) & 19 & 2224,0 & & & & $2-3$ \\
\hline Özel araç (3) & 87 & 3622,4 & & & & \\
\hline Toplu taşıma (4) & 2 & 5862,5 & & & & \\
\hline
\end{tabular}

Tablo 8'deki verilere göre, ailelerin EÇBE eğitim harcamalarının öğrencilerin devam ettiği okul olan ulaşım türü bakımından anlamlı bir şekilde farklılaştı̆̆ görülmektedir $\left(X^{2}(3)=16,209, p<, 05\right)$. Bu farkl1lı̆̆ın hangi gruplar arasında olduğunu tespit etmek için, Post Hoc testlerinden Tamhane's T2 testine başvurulmuştur. Buna göre, okula ulaşım türü servisle ( $\left.\bar{X}_{\text {servis }}=4305,9\right)$ olan ailelerin eğitim harcamaları ulaşım türü yaya ( $\bar{X}_{\text {yaya }}=2224,0$ ) olanlardan; çocuğun ulaşımın aile bireyleri tarafından kendi özel arabaları ( $\bar{X}_{\text {ara- }}$ bayla $=3622,4)$ olan ailelerin, yaya $\left(\bar{X}_{\text {yaya }}=2224,0\right)$ olan ailelerle karşılaştırıldığında daha fazla olduğu görülmektedir. Bu bulgular, ailelerin EÇBE eğitim harcamaları üzerinde çocuğun okula ulaşım türünün belirleyici bir değişken olduğunu göstermektedir.

Tablo 9'da anne eğitim düzeyine göre, ailelerin EÇBE eğitim harcamalarına ilişkin Kruskal Wallis H Test sonuçlarına bulgulara ilişkin bulunmaktadir.

Tablo 9. Anne eğitim düzeyine göre, ailelerin EÇBE eğitim harcamalarna ilişkin kruskal wallis $h$ test sonuçları

\begin{tabular}{lllllll}
\hline Eğitim Düzeyi & $\mathbf{n}$ & $\bar{x}$ & $\mathbf{S d}$ & $\mathbf{X}^{2}$ & $\mathbf{p}$ & Anlamlı fark \\
\hline İlkokul (1) & 9 & 2810,0 & 4 & 16,327 & $0,003^{*}$ & $2-4^{*}$ \\
\hline Ortaokul (2) & 6 & 2175,7 & & & & $2-5^{*}$ \\
\cline { 2 - 6 } Lise (3) & 35 & 2863,1 & & & & \\
\cline { 2 - 6 } Üniversite (4) & 116 & 4007,4 & & & & \\
Lisansüstü (5) & 26 & 4900,4 & & & & \\
\hline
\end{tabular}

${ }^{*} \mathrm{p}<, 05$

Tablo 9'daki veriler dikkate alındığında, annelerin eğitim düzeyleri ile ailelerin EÇBE eğitim harcamaları arasında anlamlı bir fark bulunmaktadır 
$\left(X^{2}(5)=16,317, \mathrm{p}<.05\right)$. Bu farkın hangi gruplar arasında olduğunu bulmak için, Post Hoc testlerinden Tamhane's T2 testine başvurulmuştur. Yapılan test sonucunda; anne eğitim düzeyi üniversite ( $\bar{X}_{\text {üniversite }}=4007,4$ ) olan ailelerin harcamaları, anne eğitim düzeyi ortakokul ( $\left.\bar{X}_{\text {ortaokul }}=2175,7\right)$ olan ailelerin yapmış oldukları harcamalardan; anne eğitim düzeyi lisansüstü ( $\bar{X}_{\text {Lisansüstü= }}$ $4900,4)$ olan ailelerin harcamaları, anne eğitim düzeyi ortaokul ( $\bar{X}_{\text {ortaokul= }}$ $2175,7)$ olan ailelerin yapmış olduğu eğitim harcamalarından daha fazladır. Bu bulgu, anne eğitim düzeyi arttıkça, ailelerin EÇBE döneminde yapmış oldukları eğitim harcamalarının da arttığını göstermektedir.

Tablo 10'da baba eğitim düzeyine göre, ailelerin EÇBE eğitim harcamalarına ilişkin Kruskal Wallis $\mathrm{H}$ testine ilişkin bulgular bulunmaktadır.

Tablo 10. Baba eğitim düzeyine göre, ailelerin EÇBE eğitim harcamalarna ilişkin kruskal wallis $h$ test sonuçlar

\begin{tabular}{|c|c|c|c|c|c|c|}
\hline Baba Eğitim & $\mathbf{n}$ & $\bar{x}$ & Sd & $\mathrm{X}^{2}$ & $\mathrm{P}^{*}$ & Anlamlı fark \\
\hline İlkokul (2) & 5 & 3691,6 & 4 & 7,139 & ,129 & - \\
\hline Ortaokul (3) & 6 & 3130,8 & & & & \\
\hline Lise (4) & 38 & 3384,3 & & & & \\
\hline Üniversite (5) & 108 & 4026,9 & & & & \\
\hline Yüksek Lisans (6) & 31 & 3953,56 & & & & \\
\hline
\end{tabular}

Tablo 10'daki veriler incelendiğinde, baba eğitim durumuna göre, ailelerin EÇBE eğitim harcamasında anlamlı bir farklılık bulunamamıştır $\left(X^{2}(4)=7,139, p>0,05\right)$. Bu bulgudan ailelerin EÇBE eğitim harcamaları üzerinde babanın eğitim düzeyinin belirleyici bir rolü olmadığı anlaşılmaktadır.

Tablo 11'de anne meslek durumuna göre, ailelerin EÇBE eğitim harcamalarına ilişkin Kruskal Wallis H Test sonuçları bulgular bulunmaktadır.

Tablo 11. Anne meslek durumuna göre, EÇBE eğitim harcamalarna ilişkin kruskal wallis h test sonuçlarn

\begin{tabular}{lllllll}
\hline Meslek & $\mathbf{n}$ & $\bar{x}$ & $\mathbf{S d}$ & $\mathbf{X}^{2}$ & $\mathbf{p}^{*}$ & Anlaml fark \\
\hline İşçi (1) & 6 & 1748,3 & 3 & 20,295 & $0,000^{*}$ & $1-2^{*}$ \\
\cline { 2 - 7 } Memur (2) & 95 & 4124,3 & & & & $1-3^{*}$ \\
\cline { 2 - 6 } Serbest (3) & 34 & 5099,3 & & & & $2-4^{*}$ \\
\cline { 2 - 5 } & 57 & 2721,9 & & & & $3-4^{*}$ \\
\hline
\end{tabular}

${ }^{*} \mathrm{p}<, 05$ 
Tablo 11'deki veriler dikkate alındığında, annelerin meslekleri ile ailelerin EÇBE eğitim harcamaları arasında anlamlı bir fark olduğu anlaşılmaktadır $\left(X^{2}(3)=20,295, p<, 05\right)$. Bu farklılığın hangi meslekler arasında olduğunu belirlemek için, Post Hoc testlerinden Tamhane's T2 testine başvurulmuştur. Buna göre, anne mesleği memur ( $\left.\bar{X}_{\text {memur }}=4124,3\right)$ olan aileler, anne mesleği işçi ( $\left.\bar{X}_{\text {iş̧i= }} 1748,3\right)$ olan ailelerden; anne mesleği serbest meslek ( $\bar{X}_{\text {serbest meslek }}$ $=5099,3)$ olan aileler, yine anne mesleği işçi ( $\left.\bar{X}_{\text {işçi }}=1748,3\right)$ olan ailelerden; anne mesleği serbest meslek ( $\left.\bar{X}_{\text {serbest meslek }}=5099,3\right)$ olan ailer, anne mesleği memur ( $\left.\bar{X}_{\text {memur }}=4124,3\right)$ ve ev kadını ( $\bar{X}_{\text {ev kadıı }}=2721,9$ ) olan ailelerden daha fazla EÇBE eğitim harcamasında bulunmaktadır.

Tablo 12' de baba meslek durumuna göre, ailelerin EÇBE eğitim harcamalarına ilişkin bulgular bulunmaktadır.

Tablo 12. Baba meslek durumuna göre, ailelerin EÇBE eğitim harcamalarna ilişkin kruskal wallis h test sonuçlan

\begin{tabular}{lllllll}
\hline Meslek & $\mathbf{n}$ & $\bar{x}$ & Sd & $\mathbf{X}^{2}$ & $\mathbf{P}^{*}$ & Anlaml fark \\
\hline İşçi & 23 & 3310,8 & 3 & 3,649 & \multirow{2}{*}{302} & \\
\cline { 2 - 7 } & & 3918,5 & & & & \\
Memur & 99 & 3816 & & & & \\
Esnaf & 16 & 3036,7 & & & & \\
Serbest & 54 & 4223,4 & & &
\end{tabular}

$P^{*}>0.5$

Tablo 12' de yer alan veriler ele alındığında, babaların meslekleri ile ailelerin EÇBE eğitim harcamaları arasında anlamlı bir fark bulunmamıştır. Bu bulgu EÇBE eğitim harcamaları üzerinde baba meslek durumunun belirleyici bir değişken olmadığını göstermektedir.

Tablo 13'te anne çalışma durumuna göre, ailelerin EÇBE eğitim harcamalarına yönelik Kruskal Wallis $\mathrm{H}$ testi veri bulunmaktadır.

Tablo 13. Anne çalışma durumuna göre, ailelerin EÇBE eğitim harcamalarnna ilişkin kruskal wallis $h$ test sonuçlan

\begin{tabular}{|c|c|c|c|c|c|c|}
\hline $\begin{array}{l}\text { Çalışma } \\
\text { Durumu }\end{array}$ & n & $\bar{x}$ & Sd & $\mathrm{X}^{2}$ & p & Anlamlı fark \\
\hline Özel Sektör (1) & 67 & 4402,5 & 4 & 10,361 & $0,035^{*}$ & $2-4^{*}$ \\
\hline Kamu/daimi kadrolu (2) & 113 & 4252,6 & & & & \\
\hline Kamu geçici işçi (3) & 2 & 4556,7 & & & & \\
\hline Çalışmıyor (4) & 4 & 2761,8 & & & & \\
\hline İsssiz (5) & 6 & 2566,7 & & & & \\
\hline
\end{tabular}

$\mathrm{p}<0.05$ 
Tablo 13'teki verilere göre, annelerin çalışma durumu ile ailelerin EÇBE eğitim harcamaları arasında anlamlı bir fark vardır $\left(X^{2}{ }_{(4)}=10,361, p<, 05\right)$. Bu farklılığın hangi gruplar arasında olduğunu belirlemek üzere Post Hoc testlerinden Tamhane's T2 testi uygulanmıştır. Yapılan bu test sonucuna göre, kamu hizmetinde daimi kadroda çalışan annelerin $\left(\bar{X}_{\text {kamu daimi }}=4252,6\right)$, çalışmayan kadırnlarla ( $\bar{X}_{\text {çalışmı̀r }=2761,8)}$ karşılaştırıldı̆̆ında EÇBE eğitim harcamalarının daha faza olduğu görülmektedir.

Tablo 14'te baba çalışma durumuna göre, ailelerin EÇBE harcamalarının ortaya koymak için yapılan Kruskal Wallis H Test ilişkin analiz sonuçları yer almaktadir.

Tablo 14. Baba çalışma durumuna göre, ailelerin EÇBE eğitim harcamalarna ilişkin kruskal wallis $h$ test sonuçlar

\begin{tabular}{|c|c|c|c|c|c|c|}
\hline $\begin{array}{l}\text { Çalışma } \\
\text { rumu }\end{array}$ & $\mathbf{n}$ & $\bar{x}$ & Sd & $X^{2}$ & $\mathrm{p}$ & Anlamlı fark \\
\hline Özel Sektör (1) & 67 & 3723,3 & 4 & 4,338 & ,362 & \\
\hline Kamu/daimi kadrolu (2) & 113 & 3854,7 & & & & \\
\hline Kamu Geçici işçi (3) & 2 & 1475,0 & & & & \\
\hline Çalışmiyor (4) & 4 & 2934,8 & & & & \\
\hline İşsiz (5) & 6 & 5181,8 & & & & \\
\hline
\end{tabular}

$\mathrm{p}<0.05$

Tablo 14 incelendiğinde, babaların çalışma durumu ile ailelerin EÇBE eğitim harcamaları arasında anlamlı bir fark bulunamamıştır. Bu bulgudan babaların çalışma durumunun ailelerin EÇBE eğitim harcamaları üzerinde belirleyici olmadığı anlaşılmaktadır.

Tablo 15'te aylık gelire göre, ailelerin EÇBE eğitim harcamalarına ilişkin Kruskal Wallis $\mathrm{H}$ testi bulguları yer almaktadır.

Tablo 15. Aylık gelire göre, ailelerin EÇBE eğitim harcamalarna ilişkin kruskal wallis $h$ test sonuçları

\begin{tabular}{lllllll}
\hline Aylık Gelir/TL & $\mathbf{n}$ & $\overline{\boldsymbol{x}}$ & $\mathbf{S d}$ & $\mathbf{X}^{2}$ & $\mathbf{p}^{*}$ & Anlaml fark \\
\hline $1600-3000(1)$ & 32 & 2542,3 & 3 & 15,656 &, 001 & $1-3$ \\
\cline { 2 - 7 } $3001-5000(2)$ & 49 & 3683,9 & & & & \\
\cline { 2 - 7 } 5001-10000(3) & 90 & 4355,2 & & & \\
\cline { 2 - 7 } $10001-18000(4)$ & 3 & 8618,3 & & &
\end{tabular}

Tablo $15^{\prime}$ te yer alan veriler dikkate alındığında, aylık gelir ile ailelerin EÇBE eğitim harcamaları arasında anlamlı bir fark vardır $\left(X^{2}(3)=15,656\right.$, 
$\mathrm{p}<, 0.05)$. Anlamlı farklılı̆̆ın hangi gruplar arasında olduğunu ortaya koymaya yönelik olarak Post Hoc testlerinden Tamhane's T2 testi uygulanmıştır. Yapilan test sonucunda aylik geliri 5001-10000 TL ( $\bar{X}=4355,2)$ arasinda olan ailelerin eğitim harcamaları aylık geliri 1600-3000 TL ( $\bar{X}=2542,3)$ arasında olan ailelerle karşılaştırıldığında daha fazladır. Bu bulgu, EÇBE eğitim harcamaları üzerinde gelirin belirleyici etkiye sahip olduğunu göstermektedir.

Tablo 16' da hanede yaşayan kişi sayısına göre, ailelerin EÇBE eğitim harcamalarına ilişkin Kruskal Wallis H testine yönelik bulgular bulunmaktadır.

Tablo 16. Hanede yaşayan kişi sayısı göre, EÇBE eğitim harcamalarna ilişkin kruskal wallis $h$ test sonuçlarn

\begin{tabular}{lllllll}
\hline $\begin{array}{l}\text { Hanedeki } \\
\text { kişi sayıs }\end{array}$ & $\mathrm{n}$ & $\bar{x}$ & $\mathrm{Sd}$ & $\mathrm{X}^{2}$ & $\mathrm{p}$ & Anlaml fark \\
\hline 2 & 4 & 7797,50 & 6 & 14,224 &, 027 & $3-7$ \\
\hline 3 & 52 & 3293,4 & & & $4-6$ \\
\hline 4 & 93 & 3971,2 & & & $4-7$ \\
\hline 5 & 28 & 4451,4 & & & $5-6$ \\
\hline 6 & 9 & 2029,1 & & & $5-7$ \\
\hline 7 & 3 & 1752,0 & & & \\
\hline 8 & 2 & 5140,0 & & & \\
\hline$P^{*}>0.05$ & & & & &
\end{tabular}

Tablo 16 incelendiğinde, hanede yaşayan kişi sayısı ile ailelerin EÇBE eğitim harcamaları arasında anlamlı bir fark vardır $\left(X^{2}=14,224, p<, 05\right)$. Bu anlamlı farklılığın hangi gruplar arasında olduğunu ortaya koymak için, Post Hoc testlerinden Tamhane's T2 testine başvurulmuştur. Söz konusu test sonucunda hane nüfusu 3 kişi ( $\bar{X}=3293,4$ ) olan ailelerdeki EÇBE eğitim harcaması, hane nüfusu 7 kişi ( $\bar{X}=1752,0)$ olanlardan; hane nüfusu 4 kişi ( $\bar{X}$ $=3971,2)$ olan ailelerin EÇBE harcamaları hane nüfusu 6 kişi ( $\bar{X}=2029,1)$ olanlar ile hane nüfusu 7 kişi ( $\bar{X}=1752,0)$ olanlardan; hane nüfusu 5 kişi ( $\bar{X}$ $=4451,4)$ olanlar, hane nüfusu 6 kişi $(\bar{X}=2029,1)$ ile hane nüfusu 7 kişi ( $\bar{X}$ $=1752,0)$ olanlardan daha fazla EÇBE eğitim harcaması yapmaktadır. Bu bulgu hanedeki kişi sayısı ile aile yapılan EÇBE eğitim harcamaları arasında ters orantılı bir ilişki olduğunu ortaya koymaktadır. 


\section{Tartışma ve Sonuç}

Araştırmaya katılan ailelerin EÇBE döneminde bulunan bir çocuk için yapmış oldukları eğitim harcaması toplam (kamu okulları ve özel okullar) 9.663,5 TL olarak hesaplanmıştır. Ancak, bu harcama miktarı çocuklarını kamu ve özel EÇBE okullarına gönderen ailelere göre farklılaşmaktadır. Buna göre, çocuklarını özel EÇBE okullarına gönderen ailelerin yapmış olduğu harcama miktarı (6.222,4 TL) kamu EÇBE okullarına gönderen ailelerin yapmış olduğu harcama miktarından $(3.411,1 \mathrm{TL})$ yaklaşık iki kat daha fazladır. Bu bulgu beklenen bir bulgudur. Özel okulların çalışma saatleri, uyguladıkları eğitim programları ve sundukları diğer hizmetlerler bakımından kamu okullarına alternatif oluşturdukları bilinmektedir. Bütün bunların yanı sıra, özel okullar piyasa koşullarında hizmet verdikleri için ailelerin belli bir satın alma gücüne sahip olmasını da gerektirmektedir. Araştırmada elde edilen bu bulgu, alanyazında bulunan araştırma bulgularıyla örtüşmektedir (Küçüker ve Aslan, 2010; Sarışık, 2019; TÜIK, 2002; Ulusoy ve Yolcu, 2014). Örneğin, Sarışık'ın (2019) kamu okulları üzerinden yürüttüğü araştırmasında, kentsel yerleşim alanlarında yaşayan ailelerin (5.539 TL) kırsal yerleşim alanlarında yaşayan ailelerin (1.754 TL) yaklaşık üç katı kadar EÇBE harcamasında bulundukları ortaya konmuştur. TÜIK'in (2002) yapmış olduğu eğitim harcamaları araştırmasında ise çocuklarını özel okullara gönderen ailelerin yapmış olduğu EÇBE harcamaları, kamu okullarına gönderen ailelerin yamış oldukları eğitim harcamalarının yaklaşık iki katıdır. Ulusoy ve Yolcu'nun (2013) ilgili araştırmasında, çocuklarını özel ilköğretim okullarına gönderen ailelerin eğitim harcamalarının kamu okullarına gönderen ailelerin eğitim harcamalarından, beş kat daha fazla olduğu gözlenmiştir.

Ailelerin çocukları için yapmış oldukları eğitim harcamaları üzerinde sahip oldukları toplumsal, kültürel ve dini değerlerler az ya da çok belirleyici olabilmektedir (Yolcu, 2011). Bu durum, az gelişmiş ve gelişmekte olan ülkelerde daha belirgin ol-duğu görülmektedir. Bunun arkasında yatan toplumsal olgu ise yetişkin erkek çocukların gelecekte ailenin ekonomik yükünü üstleneceği, kız çocuklarının ise evlenip evden gideceği düşüncesidir. Dolay1sıyla, bu ataerkil bakış açısına sahip aileler kız çocuklarından ziyade, erkek çocuklarının eğitimine yatırım yapmayı tercih edebilmektedir (Aslan, 2011; 2015; Hill ve King 1995; Yolcu, 2011). Bu araştırmada elde edilen bulgu ailelerin EÇBE eğitim harcamalarının çocuğun cinsiyeti bakımından bir farklılık 
göstermediği yönündedir. Bunun nedenlerinden biri, örneklem grubunun küçük olmasıyla açıklanabilir. İkincisi de araştırmaya katılan ailelerin sosyoekonomik düzeyi ile açılanabilir.

Alanyazında yapılan araştırmalar, ebeveynlerin eğitim düzeylerinin çocuğa yapılan eğitim harcaması üzerinde belirleyici olduğunu göstermektedir (Aksoy, 2018; Aslan, 2017; European Commission Report (ECR) 2005; Küçüker ve Aslan, 2010; Ulusoy ve Yolcu, 2013; Ulusoy ve Yolcu, 2014; Yolcu, 2011). Araştırmaya katılan ailelerde gerek annelerin gereksekse babaların yaklaşık dörtte üçü üniversite ve üzeri eğitim düzeyine sahiptir. Araştırmada elde edilen bulgu, ailelerin eğitim düzeyi ile EÇBE eğitim harcaması arasında anlamlı bir ilişki olduğunu ortaya koymaktadır. Söz konusu bu bulgu, alayazında yapılan araştırma bulgularıyla örtüşmektedir (ECR, 2005; Ulusoy ve Yolcu, 2013; Ulusoy ve Yolcu, 2014; Yolcu, 2011). Ancak, burada belirtilmesi gerekenlerden biri de ailelerin EÇBE eğitim harcamaları üzerinde babanın değil, annenin eğitim düzeyinin daha belirleyici olduğudur. Buna göre, anne eğitim düzeyi lisans ve lisansüstü lisansüstü olan aileler, diğer ailelerle karşılaştırıldığında daha fazla eğitim harcaması yapmaktadır. Bu bulgu Streuli, Vennam ve Woodhead'un (2011) araştırma bulgusuyla örtüşmektedir. Buna göre, kentsel alanlarda yaşayan annelerin eğitim düzeyinin; çocuklarını gönderecekleri okulun kamu okulu ya da özel okul olması bakımından yapacakları tercihte belirleyici olduğu gözlenmiştir.

Meslek, bir bireyin belli bir bilgi, beceri, yetenek ve deneyim dahilinde sürekli yaptığ iş veya uğraş olarak tanımlanabilir (Aktaş ve Yolcu, 2020). Eke (1987) bireyin sahip olduğu mesleğin kendisinin ve ailesinin sosyal konumunun yanı sıra, gelir düzeyini de belirleyen önemli bir değişken olduğunu belirtmektedir. Araştırmada elde edilen bulgular, ailelerin mesleki konumları ile eğitim harcamaları arasında anlamlı bir ilişki olduğu doğrulmaktadır. Ancak, EÇBE eğitim harcamaları üzerinde babanın mesleki konumundan ziyade, annenin mesleki konumunun daha belirleyici olduğu yönündedir. Buna göre, anne mesleği memur ve serbest meslek durumunda olan ailelerin EÇBE eğitim harcamaları, anne mesleği işçi, ve ev kadını olan ailelerden daha fazladır.

Esneklik, ekonomide bir karar karşısındaki değişimin ölçüsünü ifade etmede kullanılan bir kavramdır. Buna göre, bireyin geliri artıkça mal ve hizmetlere olan isteminin artması, aksi durumda ise azalması söz konusudur. Konu eğitim harcamaları bakımından ele alındığında, ailelerin geliri arttıkça 
eğitime daha fazla harcama yapması beklenilmektedir. Alanyazında yapılan araştırmalar burada yapılan açiklamaları doğrulamaktadır (Aslan, 2017; Ebaidalla, 2018; Mauldin, Mimura, ve Lino, 2001; Ulusoy ve Yolcu, 2013; Ulusoy ve Yolcu, 2014; Yolcu, 2011). Örneğin, Ebaidalla'nın (2018) Sudan'da yapmış olduğu araştırmada, ulusal düzeyde hanehalkı gelirinde \%1'lik bir artışın ailelerin eğitim harcamalarını \%8,4 oranında artırdığı gözlenmiştir. Burada tekrar bu araştırmaya dönüldüğünde, ailelerin EÇBE eğitim harcamaları üzerinde gelirin belirleyici bir değişken olduğu belirlenmiştir. Buna göre, aylık geliri 5001-10000 TL arasında olan aileler, aylık 1600-3000 TL arasında geliri olan ailelerle karşılaştırıldığında daha fazla EÇBE eğitim harcamasında bulunmaktadır. Aslında, bu bulgunun araştırmada beklenen bir bulgu olduğunun belirtilmesi gerekmektedir. Bunun en temel nedeni, Türkiye'de EÇBE'nin zorunlu eğitimin dışında olmasıdır. Dolayısıyla, bu durum, EÇBE hizmetlerinden yararlanmayı tamamen ailelerin gönüllük ve istekliliğine b1rakmaktadır. Bu da hizmetten yararlanmada, ister çocuklarını kamu EÇBE okullarına gönderen aileler açısından olsun, ister özel EÇBE okullarına gönderen aileler açısından olsun, ailelerin belli bir yaşam standardına ve satın alma gücüne sahip olmasını gerekmektedir. Ancak bu bulgu çocuklarını özel EÇBE okullarına gönderen aileler açsından ele alındığında, söz konusu yaşam standardı ve satın alma gücünün daha belirleyici olduğunun tekrar belirtilmesinde yarar vardır. Woodhead, Ames, Vennam, Abebe, ve Streuli'nin (2009) araştırmasında, en yoksul kentsel grupta bulunan yaklaşık her üç aileden biri çocuğunu özel EÇBE okuluna gönderirken, bu oran kamu EÇBE okullarında her iki çocuktan birine çıkmaktadır.

İşgücü piyasasında, aktif olmayan yaş grubunun (0-14 yaş ile 65 yaş ve üzeri nüfus) aktif olan yaş grubuna oranı (15-64 yaş arasındaki nüfus) toplam yaş bağımlılık oranın vermektedir. Ailede aktif olmayan yaş grubundaki kişi sayısının fazla olması ekonomik bağımlılık oranını artırmaktadır. Dolayısıyla, hanedeki kişi sayısı arttıkça, ailenin hanehalkı eğitim bütçesinden her çocuk için yapacağı eğitim harcamasında düşme olması kaçınılmazdır (Yolcu ve Polat, 2015). Araştırmada, hanede yaşayan kişi sayısının EÇBE eğitim harcamaları üzerinde belirleyici olduğu gözlenmiştir. Buna göre, hanedeki kişisayısı arttıkça EÇBE eğitim harcamaları düşmektedir. Bu bulgu alanyazında yapılan diğer araştırma bulguları ile örtüşmektedir (Ebaidalla, 2018; Mauldin, Mimura, ve Lino, 2001; Ulusoy ve Yolcu, 2013; Ulusoy ve Yolcu, 2014; Yolcu, 2011). 
Sonuç olarak; çocuklarını kamu EÇBE okullarına gönderen aileler, çocuklarını özel EÇBE okullarına gönderen ailelere göre daha az eğitim harcaması yapmaktadır. Ailelerin EÇBE eğitim harcamaları üzerinde çocuğun cinsiyeti, çocuğun kiminle yaşadığı, çocuğun devam ettiği okulun türü, baba eğitim, baba meslek, baba çalışma durumunun belirleyici olmadığı ancak devam edilen okulun mülkiyeti, okula ulaşım türü, anne eğitim düzeyi, anne meslek, anne çalışma durumu, aile geliri ve hanedeki kişi sayısının belirleyici olduğu gözlenmiştir.

Araştırmada, elde edilen bulgu ve sonuçlara dayalı olarak iki öneride bulunmak mümkündür. Bunlardan ilki, ailelerin kamu ve özel EÇBE okulları tercih etme nedenleri ile yapmış oldukları eğitim harcamalarının ortaya konulmasıyla ilgilidir. İkincisi de EÇBE eğitim harcamaları üzerinde, anne ile ilgili değişkenlerin neden daha belirleyici olduğu veya olmadığını farklı aile yapılarında sorgulayan bir araştırma yapılmasıdır. 


\title{
Families' Education Expenditures During Early Childhood Care and Education
}

\author{
Hüseyin Yolcu - Esra Yeşilyurt Yalçın \\ Kastamonu University
}

Early childhood care and education (ECCE) consists of the period in life that lasts from the birth of the child until the age of compulsory education. The ECCE period which includes processes related to living, growing, development and care contains a total of four developmental periods: physical, cognitive, linguistic and socio-emotional (Gordon and Browne, 2011). Participation in high-quality ECCE services also benefit the general society significantly while also doing so for the individual that participates in such services (Bakken, Brown and Downing, 2017; Barnet, 1995; Barenet, 2011; Beşpınar and Aybars, 2013; García and Heckman and Ziff, 2019; Kağıtçıbaşı, Sunar, Bekman and Cemalcılar, 2005; Mitchell, Wylie and Carr, 2008).

The question of by whom the ECCE services shall be financed is a topic of debate. Generally, there exist two main sources of finance for ECCE, these respectively being public and private sectors. The source for public financing can be central/national governments, state/local governments, or both (Belfield, 2006). The private sources, which are the other main source of finance for ECCE, consist of educational expenditure of families/households or private legal entities/the private sector (Belfield, 2006; Ünal, 1996; Yolcu, 2011).

ECCE is provided in Turkey in public nursery classes founded within elementary schools, private nursery classes within elementary schools, public and private kindergartens, public institutions founded in accordance with article 191 of Law \#657, institutions founded under the Ministry for Family, Labor and Social Services, daycare centers opened in businesses in accordance with the Labor Law, summer and mobile kindergartens, and communitybased organizations (Kaytaz and Öztürk, 2019). It should be noted here that ECCE is not included within the compulsory education in Turkey. This situation puts heavier weight on families' roles in the financing of ECCE services.

The aim of this study is to reveal the amount of expenses made by families during the ECCE period and how the mentioned amount changes according to different factors related to the characteristics of the child and the school and 
the socio-demographic properties of families. The study is limited to the expenses families made for one child enrolled in a public or private ECCE school during the 2017-2018 educational year. The obtained amounts for expenses project annual averages.

This study is an explanatory research in the scanning method. A working group was generated using the convenience sampling method from volunteering families whose children are enrolled in public or private ECCE schools in Kastamonu Province Center during the 2017-2018 educational year. 192 families were included in the study's working group. The data included in this study was obtained via the educational expenses survey. A non-parametrical test, The Kruskal Wallis U Test, was also used in the analysis of the data together with the descriptive statistics such as percentage, frequency, and arithmetical average.

The average ECCE spending of the families included in the working group of the study is $9.633,5$ TL per child. $8.223,5 \mathrm{TL}(90,2 \%)$ of this has been spent in direct expenses, while $1410 \mathrm{TL}(9,8 \%)$ of it has been spent in indirect expenses. If private and public school expenses are to analyzed separately, the spending of families whose children are enrolled in public ECCE schools is 3.411,1 TL while the spending of families whose children are enrolled in private ECCE schools is 5.222,4 TL. The spending of families those children are enrolled in public ECCE schools consists of 2.561,1 TL (85,3\%) in direct expenses and $850 \mathrm{TL}(14,7 \%)$ in indirect expenses. It is seen that the spending of families whose children are enrolled in private ECCE schools consists of $5.662,4 \mathrm{TL}(91,3 \%)$ in direct expenses and $560 \mathrm{TL}(8,7 \%)$ in indirect expenses.

It is apparent that the spending families made for their children during the ECCE period does not depend on the sex of their children.

It is seen that the ECCE spending of families differs remarkably by the school their children are enrolled being a public or a private school. The spending of families those children are enrolled in a private ECCE school is higher than those who send their children to public ECCE schools.

The ECCE spending of families who use the school bus to provide transportation for their children are higher than those who use private vehicles, public transport, or no vehicle.

There exists a significant relation between the mothers' level of education and the ECCE spending of the family. The ECCE spending of families in which the mother has a university degree is higher than of those in which the 
level of education of the mother is elementary, middle, or high school. It is observed that there also exists a remarkable correlation between the mother's profession and the ECCE spending of the family. The ECCE spending of families in which the mother is self-employed are higher than those in which the mother is employed as a civil servant, as a worker, or is a stay-at-home mom.

It was observed that the father's level of education in a family does not have a decisive role on the ECCE spending of the family. The study also shows that the profession of the father is not a factor in determining the ECCE spending of a family. Similarly, the ECCE spending of the family is not affected by the father's employment status.

There is a notable relation between the level of income of a family and its ECCE spending. The test applied to the study group reveals that the ECCE spending of families who have 5001-10000 TL of monthly income are higher than those who have 1600-3000 TL of monthly income. This finding reveals that the level of a family's income is an important factor affecting their ECCE spending level.

The ECCE spending of families varies significantly in relation to the total number of members of their households. The ECCE spending that families of 3 people make is higher than those of 7 people, those of 4 people is higher than those of 6 people, those of 5 people is higher than those of 6 or 7 people. This indicates that an inverse proportion exists between the population of a family and its ECCE spending.

In conclusion, the families who send their children to public ECCE schools tend to spend less for educational expenses than those who send their children to private ECCE schools. It was found that the sex of the child, who the child lives with, the type of school the child is enrolled in; the educational status, profession and state of employment of the father are not deciding factors on the ECCE spending of a family but the preferred transportation type to and from school; the educational status, profession, and state of employment of the mother, and the total population of the family do affect it.

It is suggested by the results and findings gathered by the study that another study be done revealing the link between the motivations of families when they are choosing between public and private ECCE schools and their spending on education. 


\section{Kaynakça / References}

Aksoy, H. (2018). Ailelerin eğitim harcamaları. Yüksek lisasn tezi. Pamukkale Üniversitesi, Denizli.

Aktaş, E. ve Yolcu, H. (2020). Yetişkinlerin halk eğitim merkezlerindeki eğitim faaliyetlerine olan istemlerinin farklı değişkenler bakımından incelenmesi. Yaşadıkça Eğitim, 34(1), 131-151.

Aslan, G. (2011). Gender perceptions of preservice teachers. International Journal of Social Sciences Humanity Studies, 3(2), 241-254.

Aslan, G. (2015). Öğretmen adaylarının toplumsal cinsiyet algılarına ilişkin metaforik bir çözümleme. Eğitim ve Bilim, 40(181), 363-384.

Aslan, G. (2017). Öğrencilerin temel eğitimden ortaöğretime geçiş (TEOG) sınav başarılarının belirleyicileri: Okul dışı değişkenlere ilişkin bir analiz. Eğitim ve Bilim, 42(190), 211-236.

Bakken, L., Brown, L. ve Downing, B. (2017). Early childhood education: the longterm benefits. Journal of Research in Childhood Education, 31(2), 255-269. DOI:10.1080/02568543.2016.1273285.

Barnett, W.S. (1995). Long-term effects of early childhood programs on cognitive and school outcomes. The Future of Children, 5(3), 25-50.

Belfield, C.R. (2006). Financing early childhood care and education: an international review. Education for All Global Monitoring Report 2007. 2007/ED/EFA/MRT/PI/4

Belle, J. (2016). Early childhood education and care (ecec) and its long-term effects on educational and labour market outcomes. Santa Monica: RAND Corporation,

Beşpınar, F. U. ve Aybars, A.İ (2013). Erken yaşlarda çocuk refahı ve kadın istihdamı. Ankara: Unicef Yayınları.

Bildirici, Z. (2017). Türkiye ve Avrupa'da okul öncesi eğitim ekonomisinin karşılaştırmalı analizi. Yüksek lisans tezi. Marmara Üniversitesi, İstanbul.

Büyüköztürk, Ş., Çakmak, E. K., Akgün, Ö. E., Karadeniz, Ş. ve Demirel, F. (2013). Bilimsel araştırma yöntemleri (15. bs.). Ankara: Pegem Akademi.

Creswell, J. W. (2012). Educational research (4. bs.). New York, NY: Pearson.

De Vaus, D.A. (2002) Surveys in social research. (5.bs). Malaysia: SRM Production Services

Ebaidalla, E. M. (2018). Understanding household education expenditure in Sudan: Do poor and rural households spend less on education? African Journal of Economic Review, 6(1), 160-178.

Eke, B. (1987). Bir sosyal sınıf belirleyicisi olarak meslek faktörü. İstanbul Üniversitesi İktisat Faküttesi Mecmuası, 43, 377-401. 
European Commission Report. (2005). Private household spending on education and training final project report. file:///D:/Downloads/Report\%20(1).pdf adresinden 24.04.2020 tarihinde erişilmiştir.

Fraenkel, J. R. ve Wallen, N. E. (2011). How to design and evaluate research in education. New York: McGraw-Hill.

García, J.L, Heckman, J.J, ve Ziff, A.L. (2019). Early childhood education and crime. Infant Ment Health Journal, 4(1), 141-151.

Gordon, A.M. ve Browne, K. W. (2011). Beginnings and beyond: foundations in early childhood education (8. bs). Wadworth: Cengage Learning.

Gravetter, F.J. ve Forzano, Lori-Ann B. (2012). Research methods for the behavioral sciences (4th edition). Wadsworth: Cengage Learning.

Gravetter, F.J. ve Forzano, Lori-Ann B. (2018). Research methods for the behavioral sciences (8. bs). Wadsworth: Cengage Learning.

Hill, M.A., King, E.M., (1995). Women's education and economic well-being. Feminist Economics 1(2), 21-46 1354-570

Kağıtçıbaşı, Ç., Sunar, D., Bekman, S. ve Cemalcılar, Z. (2005). Erken müdahalenin erişkinlikte süren etkileri: Erken destek projesi'nin ikinci takip projesi'nin ön bulguları. Anne Çocuk Eğitim Vakfı.

Kaytaz, M. ve Öztürk, N. (2019). İnsanı sermayeye krttık yatırm erken çocukluk eğıtımı. İatanbul: SETA Yayınları

Küçüker, E. ve Aslan, G. (2010). Ailelerin çocuklarının özel okullara gönderme nedenleri. World Congress of Comparative Education Societies. XIV World Congress, June 14-18 2010, Istanbul /Turkey.

Mauldin, T., Mimura, Y. ve Lino, M. (2001). Parental Expenditures on Children's Education. Journal of Family and Economic, 22, 221-241. https://doi.org/10.1023/A:1016647806016

McCollister, K.E., French, M.T. ve Fang, H. (2010). The cost of crime to society: New crime-specific estimates for policy and program evaluation. Drug and alcohol dependence, 108(1-2), 98-109. doi.org/10.1002/2176

Mitchell, L. Wylie, C. ve Carr, M. (2008). Outcomes of early childhood education: literature review report to the ministry of education. New Zealand: Ministry of Education.

Saklan, E. (2011). Türkiye'de okul öncesi eğitim politikaları, finansmanı. Yayınlanmamış yüksek lisans tezi. Gaziosmanpaşa Üniversitesi, Tokat.

Saklan, E. ve Erginer, A. (2016). Türkiye'de okul öncesi eğitime ilişkin politika ve finansman uygulamaları. Nevş̧ehir Hacı Bektaş Veli Üniversitesi, Sosyal Bilimler Enstitüsü Dergisi, 6(2), 15-44. 
Sarışı, D. (2019). Okul öncesi eğitime yönelik özel harcamalar: Muğla ili Menteşe ilçesi örneği. Yüksek lisans tezi. Muğla Sıtkı Koçman Üniversitesi, Muğla.

Save the Childeren. (2020). Investing in early childhood programs globally. https:/www.savethechildren.org/content/dam/usa/reports/ed-cp/ece-philanthropy.pdf adresinden erişilmiştir.

Shomos, A. (2010). Links between literacy and numeracy skills and labour market outcomes. P. C. S. W. Paper. Melbourne.

Streuli, N, Vennam, U. ve Woodhead, M. (2011). Increasing choice or inequality? Pathways through early education in Andhra Pradesh, India. Bernard van Leer Foundation.

Şimşek, A. (2015). Araştrıma modelleri. A. Şimşek Ed. Sosyal bilimlerde araştırma. Eskişehir: Anadolu Üniversitesi Yayını No. 2653

The United Nations Educational, Scientific and Cultural Organization (2016). Asiapacific regional report: financing for early childhood care and education (ecce). Bankok: UNESCO

The United Nations Educational, Scientific and Cultural Organization (2004). Early childhood care and education in e-9 countries: status and outlook. Prepared for The Fifth E-9 Ministerial Meeting Cairo, Egypt, December 19-21, 2003. https://unesdoc.unesco.org/ark:/48223/pf0000135471 adresinden erişilmiştir.

Tiyab, B.K. ve Ndabananiye, J.C. (2013). Household education spending, Approach and estimation techniques using household surveys, methodological guidelines. Dakar: UNESCO.

Toran, M. (2011). Montessori yönteminin çocukların kavram edinimi, sosyal uyumları ve küçük kas motor becerileri üzerindeki etkisinin incelenmesi Doktora tezi. Gazi Üniversitesi, Ankara.

Türkiye İstatistik Kurumu (2002). Türkiye eğitim harcamaları araştırması. Ankara: TÜİK Matbaası.

Türkiye İstatistik Kurumu (2020). Eğitim harcamalan istatistikleri. http://www.tuik.gov.tr/PreTablo.do?alt id=1018 adresinden erişilmiştir.

Ulusoy, B. ve Yolcu, H. (2014). Çocuklarını kamu okullarına gönderen ailelerin ilköğretim düzeyinde yapmış oldukları eğitim harcamaları. Kastamonu Üniversitesi Ĕ̆itim Fakültesi Dergisi, 22(3), 1091-1112.

Ulusoy, B. ve Yolcu, H. (2013). Household education expenditure of families at primary education level. Journal of Educational Sciences Research, 3(1), 1-27.

Ünal, L. I. (1996). Eğitim ve yetiştirme ekonomisi (1.bs). Ankara: Epar Yayınları.

Woodhead, M., Ames, P., Vennam, U., Abebe, W. ve Streuli. N. (2009). Equity and quality? Challenges for earl childhood and primary education in Ethiopia, 
India and Peru. Working Paper 55. The Hague, The Netherlands: Bernard van Leer Foundation

Yolcu, H. (2011). Hanehalkının eğitim harcamalarını etkileyen etmenler: kuramsal bir çalışma. Mehmet Akif Ersoy Üniversitesi Sosyal Bilimler Enstitüsü Dergisi, 3(5), 12-35.

Yolcu, H. (2019). Erken çocukluk döneminde ailelerin evde ücretli bakım hizmetlerine yönelik talepleri. Erken Çocukluk Çalışmaları Dergisi, 3(2), 228-257. doi:http://dx.doi.org/10.24130/eccd-jecs.1967201932155.

Yolcu, H. ve Polat, S. (2015). Eğitime erişimde farklı değişkenlerin belirleyiciliği üzerine kuramsal bir çalışma. Ed. K. Karakütük. Prof. Dr. Mahmut Âdem'e armă̆an kitabı içinde (s. 349-382). Ankara: Ankara Üniversitesi Basımevi.

\section{Kaynakça Bilgisi / Citation Information}

Yolcu, H. ve Yeşilyurt Yalçın, E. (2020). Ailelerin erken çocukluk bakımı ve eğitimi dönemi eğitim harcamaları. OPUS-Uluslararası Toplum Araştırmaları Dergisi, 16(30), 2448-2477. DOI: 10.26466/opus.733398 